Cambridge in 1921 as a research student under the late Sir Frederick Gowland Hopkins. These were the pioneering days of enzymology, which saw its development into an exact science, and it was to this field that Prof. Quastel made some of his most important contributions. His exhaustive studies of the resting metabolism of bacteria, which form the basis of present-day microbiological techniques, led to the characterization of new enzyme systems, while his discovery of the specific competitive inhibitors of enzyme action has had the widest application in this field. Prof. Quastel's fundamental contribution at this time was his work on the reversibility of dehydro. genase action. Working with succinic dehydrogenase, he showed that the change in free energy determined from the observed equilibrium point agreed closely with the value calculated from thermal data.

In 1929 Prof. Quastel was appointed director of research to the Cardiff City Mental Hospital, where he investigated the biochemical aspects of mental disease. Fruitful results arising from the integration of clinical and research aspects of these problems has encouraged the development of similar units elsewhere. Following the outbreak of war, Prof. Quastel accepted in 1941 the invitation of the Agricultural Research Council to organise a Unit of Soil Biochemistry at Rothamsted. In this field his work showed the same originality of outlook that was apparent in his earlier work. By repeated percolations of a small quantity of soil by an aqueous solution in a closed circuit and periodic addition of reagents or removal of samples for analysis, detailed qualitative data on soil metabolism, in particular nitrogen metabolism, were obtained. Prof. Quastel was awarded the Meldola Medal in 1927, and was elected a fellow of the Royal Society in 1940. One can with confidence anticipate the development, under his guidance, of a vigorous school of cellular metabolism at MeGill University.

\section{Institute of Fuel : New Building}

THE Institute of Fuel was founded in 1927, soon after the general strike in Britain-a national disaster which started much thought about fuel problems. In several directions action was taken to establish new technical organisations which eventually, by processes of mutual attraction or absorption, led to the foundation of this Institute of Fuel. After ten years or so of useful work, the Institute gathered together about 1,000 members. Then came the War to provide new tasks and opportunities for service which the staff and members were able and ready to seize. As a result, its roll of members has since increased threefold. Regional sections have been formed, schemes of education have been launched, including examinations to qualify for membership, and in 1946 a petition for incorporation by Royal Charter was granted. This year, in order to carry on its work more effectively, the Institute has acquired permanent headquarters at 18 Devonshire Street, London, W.1. It has issued an appeal to all who are interested to contribute sums in support. Already about $£ 8,000$ has been received. Cheques should be addressed to the Secretary, Institute of Fuel, 18 Devonshire Street, London, W.I.

\section{Civil Aircraft Research}

Ir has been announced that the terms of reference of the Civil Aircraft Research Committee of the Aeronautical Research Council are: "To consider the basic research problems arising from the evolution and operation of civil aircraft, having regard, inter alia, to the probable requirements of the operators; to recommend periodically to the Council programmes of research; and to report to the Aeronautical Research Council". The members are Prof. A. A. Hall (chairman), Prof. A. R. Collar, Dr. T. E. Easterfield, Prof. S. Goldstein, Major F. M. Green, Sir Melville Jones, Prof. R. L. Lickley, Dr. H. R. Ricardo, Mr. P. A. Sheppard, Prof. G. Temple, and representatives of the Ministry of Supply, the Ministry of Civil Aviation, the National Physical Laboratory, and the three airways corporations.

\section{Zoological Society of Bengal}

THE Government of India has recently decided to transfer the office of the Zoological Survey of India from Calcutta to Delhi. As a result, the zoologists of Bengal will be deprived of the use of the only zoological library in that part of the country. In order to meet this difficulty, the Zoological Society of Bengal is issuing an appeal for assistance in the hope that zoologists will present them with reprints of their papers and put the Society on their mailing lists. The Zoological Society of Bengal was only founded last year, but the annual report for 1946 shows that already 294 members have been enrolled and various meetings held. Among the speakers has been Prof. H. Munro Fox, one of the British delegates to the Indian Science Congress Association. The Society proposes to issue monographs of typical Indian animals and also a bulletin dealing with simple zoological laboratory technique. It also hopes to publish a journal devoted to zoological research in India. The president is Prof. H. K. J. Mookerjee, and secretary, Dr. S. P. Ray Chaudhuri. The Society's address is 35 Ballygunge Circular Road, Calcutta.

\section{A Science Journal for South Africa}

At a meeting of the South African Association for the Advancement of Science, held in Johannesburg on May 16, it was resolved that the Association should commence publication at the earliest possible date of a monthly periodical covering the whole field of science. The venture will be paid for by the Association and will not be in any way a profit-making organisation; it is intended that the journal should be distributed free to all members of the Association, and that it may later be made available for sale to the public. It is hoped to present leading articles, reviews of books, and articles of a general character, and to devote three or four pages to "Letters to the Editor", a section which it is hoped will become a forum for scientific discussion. It is intended that articles, etc., should be of such a nature as to appeal to scientific workers in fields other than those of their own speciality, and it is believed there will be sufficient popular material to appeal to the more general reader of scientific interests. The journal will be produced by the Association, the honorary editor being Dr. H. B. S. Cooke, of the University of the Witwatersrand.

\section{American Institute of Physics}

The January issue of the Review of Scientific Instruments contains an important announcement concerning the reorganisation of the American Institute of Physics. The five societies, the American Physical Society, the Optical Society of America, the Acoustical Society of America, the Society of Rheology and the Amorican Association of Physics 